\title{
Analysis of chicken macrophage functions and gene expressions following infectious bronchitis virus M41 infection
}

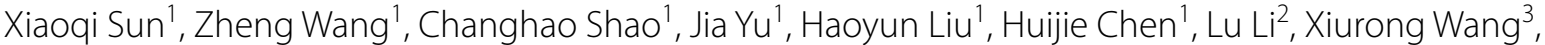 \\ Yudong Ren ${ }^{4}$, Xiaodan Huang ${ }^{1}$, Ruili Zhang ${ }^{1}$ and Guangxing Li ${ }^{1 *}$ (D)
}

\begin{abstract}
Infectious bronchitis virus (IBV) is a pathogenic coronavirus with high morbidity and mortality in chicken breeding. Macrophages with normal biofunctions are essential for host immune responses. In this study, the HD11 chicken macrophage cell line and chicken peripheral blood mononuclear cell-derived macrophages (PBMCs-M $\varphi$ ) were infected with IBV at multiplicity of infection (MOI) of 10. The dynamic changes of their biofunctions, including cell viability, pathogen elimination function, phagocytic ability, and gene expressions of related proteins/mediators in innate and acquired immunity, inflammation, autophagy and apoptosis were analyzed. Results showed that IBV infection decreased chicken macrophage viability and phagocytic ability, and increased pathogen elimination function. Moreover, IBV augmented the gene expressions of most related proteins in macrophages involved in multiple host bioprocesses, and the dynamic changes of gene expressions had a close relationship with virus replication. Among them, MHCII, FC receptor, TLR3, IFN-a, CCL4, MIF, IL-1ß, IL-6, and iNOS showed significantly higher expressions in IBV-infected cells. However, TLR7, MyD88, MDA5, IFN- $y$, MHCII, Fc receptor, MARCO, CD36, MIF, XCL1, CXCL12, TNF-a, iNOS, and IL-10 showed early decreased expressions. Overall, chicken macrophages play an important role in host innate and acquired immune responses to resist IBV infection, despite early damage or suppression. Moreover, the IBV-induced autophagy and apoptosis might participate in the virus-host cell interaction which is attributed to the biological process.
\end{abstract}

\section{Introduction}

Infectious bronchitis (IB) is a highly contagious respiratory disease in chickens with worldwide distribution and economic significance [1]. IB is caused by infectious bronchitis virus (IBV) which is a single-stranded, positive-sense enveloped RNA virus of the Coronavirus family [2]. IBV was first described in the 1930s in the USA [3]. The IBV Massachusetts 41 (M41) strain was subsequently isolated and assigned to the Massachusetts

\footnotetext{
${ }^{*}$ Correspondence: ligx@neau.edu.cn

1 Department of Basic Veterinary Science, College of Veterinary Medicine, Heilongjiang Key Laboratory for Animal and Comparative Medicine, Northeast Agricultural University, Harbin 150030, China

Full list of author information is available at the end of the article
}

serotype $[4,5]$, which is frequently used in experimental and clinical research [6,7]. IBV is liable to mutate and recombine, which gives rise to multiple serotypes $[2,8]$. Generally, the available commercial IB vaccines may not trigger powerful immune responses, provide reciprocal protection among different serotypes of IBV infections, and lead to huge economic losses [9]. Therefore, it is necessary to understand the mechanism of host immune responses to IBV infection.

Macrophages are important innate immune effectors against microbial infections and participate in innate immune responses and the subsequent acquired immunity [10]. Pattern recognition receptors (PRRs) in macrophages can recognize the pathogen-associated 
molecular pattern (PAMP) [11]. Various intracellular signals are triggered subsequently to promote the production of immunomodulation molecules [12, 13] and activate the processing pathways of antigen presentation in macrophages to switch on acquired immune responses [14]. Also, macrophage-programmed cell death-related genes changed in defense against pathogens $[6,15]$. It has been shown that IBV could significantly increase the number of macrophages in chicken respiratory tracts [16]. However, the immune function and immune regulation of macrophages in IBV infection remain mostly unclear. In this study, HD11 chicken macrophage cells and chicken peripheral blood mononuclear cell-derived macrophages (PBMCs-M $\phi$ ) were infected with IBV M41 strain, and the dynamic changes of macrophage functions and gene expressions of related proteins/mediators in innate and acquired immunity, inflammation, autophagy and apoptosis were systematically analyzed.

\section{Materials and methods \\ Cells and virus}

HD11 cells were kindly provided by Dr. Yulong Gao (Harbin Veterinary Research Institute, Chinese Academy of Agricultural Science). HD11 cells were cultured in RPMI 1640 complete medium at $1.5 \times 10^{5}$ cells $/ \mathrm{mL}$ and were kept at $41{ }^{\circ} \mathrm{C}$ in $5 \% \mathrm{CO}_{2}$. PBMCs-M $\phi$ were separated from chicken blood based on a previous method with minor modifications [17]. In brief, pooled whole blood in $10 \mathrm{U} / \mathrm{mL}$ heparins (Ncbiotech Co., Ltd, Harbin, China) was collected from 3-month-old specific-pathogen-free (SPF) chickens by heart punctures. PBMCs were separated by Ficoll-Hypaque (Tianjin Hao Yang Biological Manufacture Co., Ltd, Tianjin, China) density gradient centrifugation according to the manufacturer's instructions. After being cleaned with $1 \times \mathrm{PBS}(\mathrm{pH} 7.2)$, PBMCs were seeded in $2 \times 10^{7}$ cells $/ \mathrm{mL}$ in RPMI 1640 complete medium for $24 \mathrm{~h}$ and incubated at $41{ }^{\circ} \mathrm{C}$ in $5 \%$ $\mathrm{CO}_{2}$. Finally, nonadherent cells in the supernatant were removed. The procedures of the experiment complied with the Northeast Agriculture University Health Guidelines for the Care and Use of Laboratory Animals.

IBV strain M41 (Accession number: DQ834384.1) was preserved in the Veterinary Pathology Laboratory, College of Veterinary Medicine in Northeast Agricultural University. The virus was propagated in 9-11-day-old SPF chicken embryos.

\section{KUL01 + cell assay}

The purity of HD11 cells and PBMCs-M $\phi$ were evaluated with flow cytometry via staining of chicken macrophage marker, KUL01 [18]. PBMCs-M $\phi$ and HD11 cells were dispersed with $1 \%$ trypsin into a single-cell solution and fixed with $1 \%$ paraformaldehyde for $30 \mathrm{~min}$. The cells were incubated with mouse anti-chicken monocyte/ macrophage antibodies KUL01 (1: 50, Bio-Rad, USA) for $30 \mathrm{~min}$. After being washed 3 times with PBS, FITC labeled goat anti-mouse IgG (1: 50, ZSGB-Biotechnology Co., Ltd, Beijing, China) was added and incubated in the dark for $30 \mathrm{~min}$. Washed cells were assayed by flow cytometry (BD FACSAria II, USA).

\section{IBV infection in macrophages}

HD11 cells and PBMCs-M $\phi$ were seeded in 6-well plates and grown to $80 \%$ confluence. Macrophages were infected with IBV at a multiplicity of infection (MOI) of 10. After being incubated for $2 \mathrm{~h}$ at $41^{\circ} \mathrm{C}$, the virus was replaced with RPMI 1640 supplemented with $2 \%$ FBS. Cytopathic effects (CPE) were observed daily. Virus titers were determined by endpoint dilutions as $50 \%$ tissue culture infective dose $\left(\mathrm{TCID}_{50}\right)$ at $6,12,18,24,30,36,42$ and $48 \mathrm{~h}$ post-infection (hpi) by the Reed-Muench method, as described previously [19].

Quantitative real-time polymerase chain reaction (qRT-PCR) was also carried out to detect IBV. Total RNA was extracted at 12, 24, 36, 48 hpi using TRIzol reagent (Invitrogen, Shanghai, China) according to the manufacturer's instructions. Total RNA of $1 \mu \mathrm{g}$ in each sample was reverse transcribed into cDNA using PrimeScript ${ }^{\mathrm{TM}}$ RT reagent Kit with gDNA Eraser (Perfect Real Time) (Takara Biomedical Technology Co., Ltd, Beijing, China). IBV copies were measured by IBV $\mathrm{N}$ gene copies using fluorescence quantitative PCR reagent (Bioteke Corporation, Beijing, China). The primers were designed according to the IBV N gene (Accession number: FJ904723.1) and are shown in Table 1. The steps for thermal cycling were as follows: $94{ }^{\circ} \mathrm{C}, 2 \mathrm{~min}$ for denaturation and 40 cycles of PCR $\left(94^{\circ} \mathrm{C}, 15 \mathrm{~s} ; 60^{\circ} \mathrm{C}, 30 \mathrm{~s}\right)$.

\section{Cell viability assay}

A CCK-8 reagent (MCE, USA) was used to detect cell viability. UV-IBV was prepared by inactivating IBV M41 with UV germicidal light for $30 \mathrm{~min}$. Cells were seeded into 96-well plates and infected with $10 \mathrm{MOI}$ IBV, or incubated with UV-IBV (same amount of virion to 10 MOI IBV), or PBS (Mock cells) in RPMI 1640 supplemented with $2 \%$ FBS. CCK- 8 reagent was added to the cells at 12, 24, 36, and $48 \mathrm{hpi}$, and they were incubated for $2.5 \mathrm{~h}$ at $41{ }^{\circ} \mathrm{C}$. The optical density (OD) values were measured with a microplate reader (ELx808, BioTek, USA) at $450 \mathrm{~nm}$, as previously described [20]. Cell viability was calculated according to the formula in the manufacturer's instructions: Cell viability $(\%)=[$ optical density $(\mathrm{OD})$ of Mock or IBV-infected or UV-IBV-treated cells-OD of medium]/[OD of Mock cells-OD of medium] $\times 100$. 
Table 1 Primer sequences for qRT-PCR

\begin{tabular}{|c|c|c|c|}
\hline Gene & Primer Sequences $\left(5^{\prime}-3^{\prime}\right)$ & Product length (bp) & Accession number \\
\hline \multirow[t]{2}{*}{ IBV N } & F: CAAGCTAGGTTTAAGCCAGGT & 218 & FJ904723.1 \\
\hline & R:TCTGAAAACCGTAGCGGATAT & & \\
\hline \multirow[t]{2}{*}{ TLR3 } & F: ACCCGGATTGCAGTCTCAGTA & 95 & NM_001011691.3 \\
\hline & R: CACTGTCCTTGCAGGCTGAG & & \\
\hline \multirow[t]{2}{*}{ TLR7 } & F: ACCGTCGCCTCAAGGAAGTCC & 145 & NM_001011688.2 \\
\hline & R: ACGCAGTTGCACCTGAAGTCAATC & & \\
\hline \multirow[t]{2}{*}{ MyD88 } & F: AAGGTGTCGGAGGATGGTGGTC & 120 & NM_001030962.4 \\
\hline & R: GGAATCAGCCGCTTGAGACGAG & & \\
\hline \multirow[t]{2}{*}{ MDA5 } & F:TCAGGAGGAGGACGACCACGAT & 168 & GU570144.1 \\
\hline & R: TTCCCACGACTCTCAATAACAG & & \\
\hline \multirow[t]{2}{*}{ IFN-a } & F: GGACATGGCTCCCACACTAC & 75 & GU119896.1 \\
\hline & R:TCCAGGATGGTGTCGTTGAAG & & \\
\hline \multirow[t]{2}{*}{$\mathrm{IFN}-\beta$} & F: GCCCACACACTCCAAAACACTG & 151 & GU119897.1 \\
\hline & R:TTGATGCTGAGGTGAGCGTTG & & \\
\hline \multirow[t]{2}{*}{ IFN- $\gamma$} & F: CACTGACAAGTCAAAGCCGC & 87 & NM_205149.1 \\
\hline & R: ACCTTCTTCACGCCATCAGG & & \\
\hline \multirow[t]{2}{*}{$\mathrm{MHCl}$} & F: GCCAACACGGACCAGCAGTAC & 81 & NM_001097530.1 \\
\hline & R: GTCCAGGTTCTCGCGGTCAATC & & \\
\hline \multirow[t]{2}{*}{$\mathrm{MHCll}$} & F: GTTCTACCAGCGTTCGGAAGGC & 101 & DQ207939.1 \\
\hline & R:TCTGAGCGGCGTCCAACTCC & & \\
\hline \multirow[t]{2}{*}{ Fc receptor } & F:TGTGAGGTGCGGACGGAGAG & 195 & AM412311.1 \\
\hline & R:TCGGTGCCAGGAGAAGGAGATG & & \\
\hline \multirow[t]{2}{*}{ MARCO } & F: CACATAAGCGAGCCTCGAATCCAG & 81 & NM_204736.1 \\
\hline & R: CAGCAGCAGCAGGTAGATGACAAG & & \\
\hline \multirow[t]{2}{*}{ CD36 } & F: ACCAGACCAGTAAGACCGTGAAGG & 154 & NM_001030731.1 \\
\hline & R: ATGTCTAGGACTCCAGCCAGTGTG & & \\
\hline \multirow[t]{2}{*}{ MIF } & F: ATTGGCAAGATTGGAGGG & 127 & M95776.1 \\
\hline & R: CGTTGGCAGCATTTATGTC & & \\
\hline \multirow[t]{2}{*}{ CCL4 } & F: GCAGTTGTTCTCGCTCTTC & 192 & NM_204720.1 \\
\hline & R: GCGCTCCTTCTTTGTGAT & & \\
\hline \multirow[t]{2}{*}{ K60 } & F: GCTGCTGTCATGGCTCTT & 278 & Y14971.1 \\
\hline & R:TTGGTGTCTGCCTTGTCC & & \\
\hline \multirow[t]{2}{*}{$X C L 1$} & F: ATGAAACTCCACGCCACAGTT & 294 & NM_205046.1 \\
\hline & R: TTATCTTCTTCTGGTAGTACG & & \\
\hline \multirow[t]{2}{*}{ CXCL12 } & F:TGTCGGAGGAGAAGCCTGTCAG & 158 & NM_204510.1 \\
\hline & R: CACTTGCTTGCTGTTGCTCTTGAG & & \\
\hline \multirow[t]{2}{*}{$\mathbb{I L}-1 \beta$} & F:TGGGCATCAAGGGCTACA & 244 & Y15006.1 \\
\hline & R:TCGGGTTGGTTGGTGATG & & \\
\hline \multirow[t]{2}{*}{ IL-6 } & F: ATGGTGATAAATCCCGATGAAG & 153 & NM_204628.1 \\
\hline & R: CCTCACGGTCTTCTCCATAAAC & & \\
\hline \multirow[t]{2}{*}{ TNF-a } & F: CAGATGGGAAGGGAATGAAC & 268 & NM_204267.1 \\
\hline & R: AGAGCATCAACGCAAAAGGG & & \\
\hline \multirow[t]{2}{*}{ NF-kB } & F:TCAACGCAGGACCTAAAGACAT & 162 & M86930.1 \\
\hline & R: GCAGATAGCCAAGTTCAGGATG & & \\
\hline \multirow[t]{2}{*}{ iNOS } & F: AGTGGTATGCTCTGCCTGCT & 171 & NM_204961.1 \\
\hline & R: CCAGTCCCATTCTTCTTCC & & \\
\hline $\mathrm{IL}-10$ & F: CAGCACCAGTCATCAGCAGAGC & 94 & NM_001004414.2 \\
\hline & R: GCAGGTGAAGAAGCGGTGACAG & & \\
\hline
\end{tabular}


Table 1 (continued)

\begin{tabular}{|c|c|c|c|}
\hline Gene & Primer Sequences $\left(5^{\prime}-3^{\prime}\right)$ & Product length (bp) & Accession number \\
\hline \multirow[t]{2}{*}{ PPAR- $\gamma$} & F: GGGCGATCTTGACAGGAA & 175 & AB045597.1 \\
\hline & R: GCCTCCACAGAGCGAAAC & & \\
\hline \multirow[t]{2}{*}{ LC3\| } & F: GTACGAGAGCGAGAAGGACG & 83 & NM_001031461.1 \\
\hline & R: AGACGGAAGATTGCACTCCG & & \\
\hline \multirow[t]{2}{*}{ mTOR } & F: CATGTCAGGCACTGTGTCTATTCTC & 77 & XM_417614.5 \\
\hline & R: CTTTCGCCCTTGTTTCTTCACT & & \\
\hline \multirow[t]{2}{*}{ Beclin-1 } & F:TGGCTTTCTTGGACTGTGTG & 125 & NM_001006332.1 \\
\hline & R: ACCACCACTGCCACCTGTAT & & \\
\hline \multirow[t]{2}{*}{ Caspase-3 } & F: CCACCGAGATACCGGACTGT & 176 & NM_204725.1 \\
\hline & R: AACTGCTTCGCTTGCTGTGA & & \\
\hline \multirow[t]{2}{*}{ Bax } & F: ACTCTGCTGCTGCTCTCCTCTC & 174 & XM_025145468.1 \\
\hline & R: ATCCACGCAGTGCCAGATGTAATC & & \\
\hline \multirow[t]{2}{*}{$\mathrm{BCl}-2$} & F: GAGTTCGGCGGCGTGATGTG & 92 & NM_205339.2 \\
\hline & R:TTCAGGTACTCGGTCATCCAGGTG & & \\
\hline \multirow[t]{2}{*}{$\beta$-actin } & F: ATTGCTGCGCTCGTTGTT & 173 & K02173.1 \\
\hline & R: CTTTTGCTCTGGGCTTCA & & \\
\hline
\end{tabular}

F: Forward primer for qRT-PCR, R: Reverse primer for qRT-PCR

\section{Nitric oxide assay}

Cells were seeded into 6-well plates. Supernatants of Mock cells, IBV-infected cells, and UV-IBV-treated cells were collected at $12,24,36$, and $48 \mathrm{hpi}$ and centrifuged at $1000 \mathrm{~g}$ for $30 \mathrm{~min}$ at $4{ }^{\circ} \mathrm{C}$. Nitric oxide (NO) content in the supernatant was detected by a NO assay kit (Nanjing Jiancheng Bioengineering Institute, Nanjing, China), as previously described [21].

\section{Macrophage phagocytic ability assay}

Phagocytic functions of macrophages were assayed according to the method of Lee et al. [17]. Briefly, yellowgreen fluorescent latex beads ( 50 beads/cell, Sigma, USA) were used to incubate with Mock cells, UV-IBV-treated cells and IBV-infected cells at $24 \mathrm{hpi}$ at $41{ }^{\circ} \mathrm{C}$ for $2 \mathrm{~h}$. Cells were then separated by $1 \%$ trypsin for macrophage phagocytic ability assay using flow cytometry. At the meantime, cells in these 3 groups were fixed with methanol for $10 \mathrm{~min}$, and stained with $0.01 \mathrm{mg} / \mathrm{mL}$ propidium iodide solution for $20 \mathrm{~min}$ for observation of phagocytic function under fluorescence microscopy (Nikon, Japan).

\section{QRT-PCR assay of gene expression}

Total RNA of cells was extracted and reverse transcribed into cDNA using PrimeScript ${ }^{\mathrm{TM}}$ RT reagent Kit with gDNA Eraser at 12, 24, 36, and 48 hpi. QRT-PCR reagents were used to detect the relative gene expressions of related factors in innate immunity (TLR3, TLR7, MyD88, MDA5, IFN- $\alpha$, IFN- $\beta$, IFN- $\gamma$ ), acquired immunity (MHCI, MHCII, Fc receptor, MARCO, CD36), chemokines (MIF, CCL4, K60, XCL1, CXCL12), inflammation (IL-1ß, IL-6,
TNF- $\alpha$, NF- $k$ B, iNOS, IL-10, PPAR- $\gamma$ ), autophagy (LC3II, mTOR, Beclin-1) and apoptosis (Caspase-3, Bax, Bcl-2). The primers are listed in Table $1 . \beta$-actin was chosen as a reference gene. The steps for thermal cycling were as follows: $94{ }^{\circ} \mathrm{C}, 2 \mathrm{~min}$ for denaturation and 40 cycles of PCR $\left(94{ }^{\circ} \mathrm{C}, 15 \mathrm{~s} ; 60{ }^{\circ} \mathrm{C}, 30 \mathrm{~s}\right)$. The expression fold changes were calculated using the $2^{-\triangle \triangle \mathrm{CT}}$ method [22].

\section{Statistical analyses}

Each treatment was analyzed in triplicate, values were expressed as mean $\pm S D$ and statistical significances were assessed by Duncan multiple range test of SPSS 19.0 software using the one-way ANOVA method. Probabilities of $p<0.05$ and $p<0.01$ were preset for statistical significance. Flow cytometry analyses were performed on FlowJo software (version 10.0.6). Figures were created with Image J and GraphPad Prism (version 5.0) software.

\section{Results}

KUL01 + cell percentages of HD11 cells and PBMCs-M $\varphi$

Both HD11 cells and PBMCs-M $\phi$ showed high positive fluorescent signals (Figure 1A). The percentages of KUL01+ cells in HD11 cells and PBMCs-M $\phi$ were $99.8 \pm 0.1 \%$ and $91.3 \pm 1.2 \%$, respectively (Figure $1 \mathrm{~B}$ ), indicating these two kinds of macrophage satisfied the needs of the experiments.

\section{IBV M41 infection in macrophages}

HD11 cells and PBMCs-M $\phi$ were infected with IBV at an MOI of 10. CPE, qRT-PCR and virus titer assays were carried out. After 5 times of adaptive cell culture 

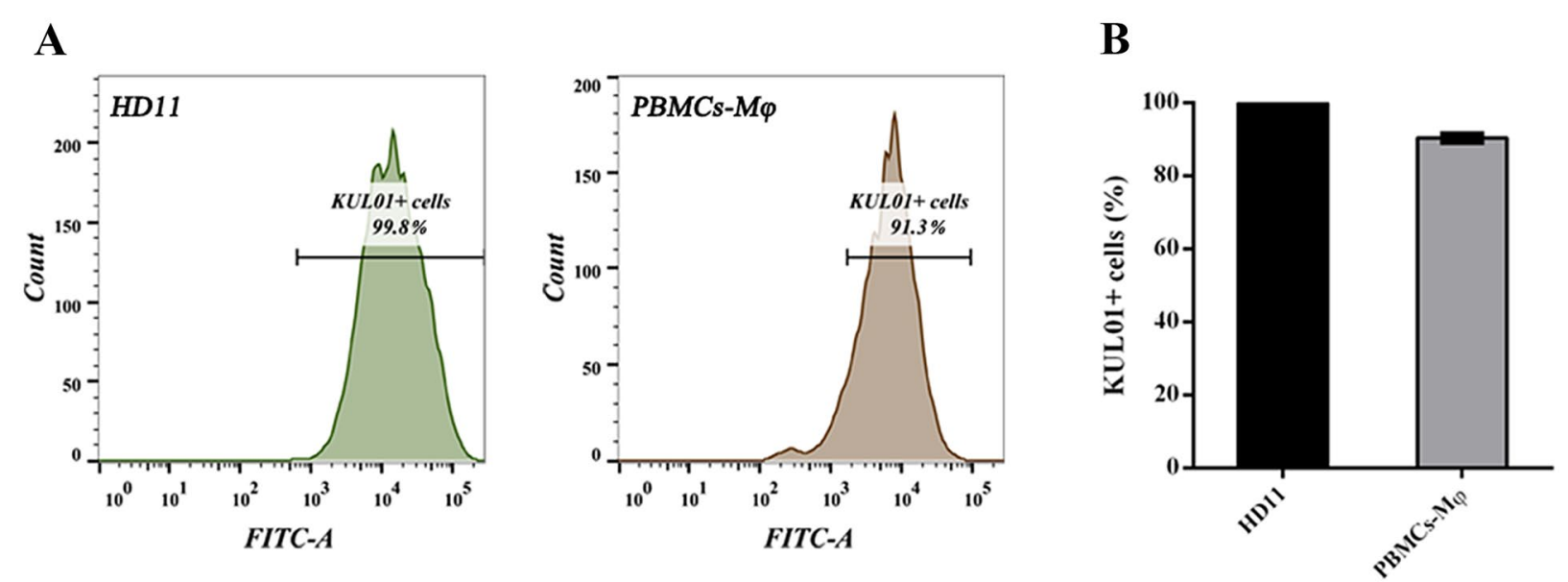

Figure 1 KUL01 + cell evaluation. A KUL01 + cells in HD11 cells and PBMCs-M $\varphi$ were evaluated by flow cytometry. B The mean percentages of $\mathrm{KUL01}+$ macrophages in HD11 cells and PBMCs-M $\varphi$ are shown in histograms. Data presented as means $\pm \mathrm{SD}(n=3)$.

of IBV M41 strain in both kinds of cell, the typical CPE appeared in macrophages at $24 \mathrm{hpi}$, and peaked at 36 hpi (Figure 2A). QRT-PCR and TCID 50 results showed IBV replication increased in a time-dependent manner, while there was a decrease at $48 \mathrm{hpi}$ (Figures 2B, C). The results indicate IBV M41 could infect HD11 cells and PBMCs-M $\phi$.

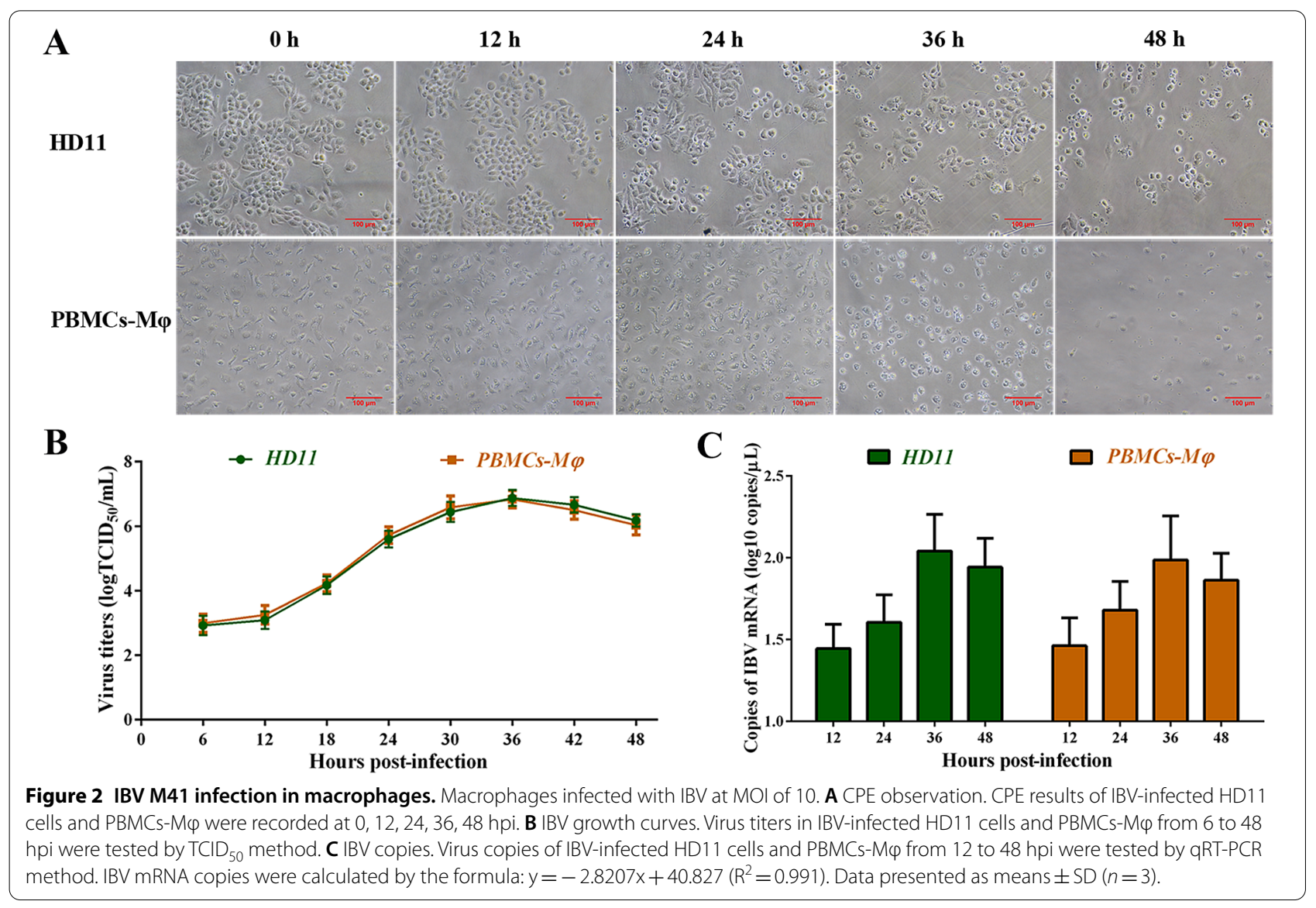




\section{IBV M41 decreased macrophage viability}

Cell viability was tested. CCK- 8 assay results showed that cell viability of IBV-infected macrophages decreased in a time-dependent manner $(p<0.01)$, while there were no significant changes in Mock cells and UV-IBV-treated cells (Figure 3A).

\section{IBV M41 activated macrophage pathogen elimination function}

NO content was examined to determine the pathogen elimination function of macrophages. NO secreted by macrophages is a key aspect of the antimicrobial response [23]. NO content increased significantly in
IBV-infected (HD11/PBMCs-M $\phi: p<0.01)$ and UV-IBVtreated (HD11: $p<0.01$, PBMCs-M $\phi: p<0.05$ ) cell supernatants at 36 hpi compared with Mock cells (Figure 3B). The up-regulated NO content of UV-IBV-treated cells was lower than that of IBV-infected cells, indicating that IBV replication stimulates NO production in chicken macrophages.

\section{IBV M41 affected macrophage phagocytic function}

Phagocytic function of macrophages was determined by detecting the percentage of macrophages phagocytizing yellow-green fluorescent latex beads by flow cytometry and fluorescence microscopy. Flow cytometry results

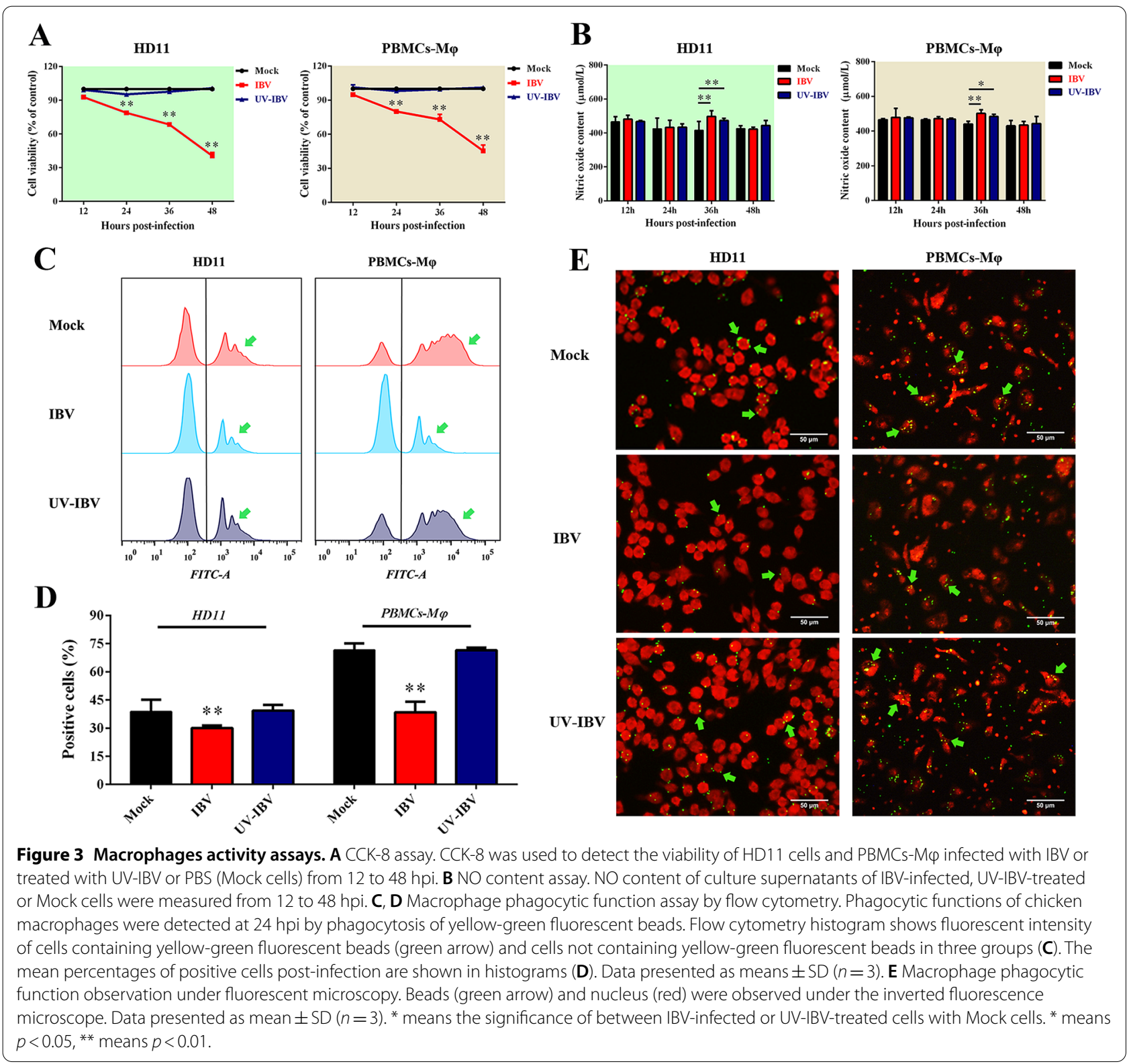


showed less yellow-green fluorescence in IBV-infected cells compared with Mock cells at 24 hpi, HD11 cells (Mock: 38.8\%, IBV: 30.0\%; $p<0.01$ ) and PBMCs-M $\phi$ (Mock: 71.5\%, IBV: 38.4\%; $p<0.01$ ). There were no significant changes in UV-IBV-treated cells (Figure 3C, D). Fluorescence microscopy results were consistent with those of the flow cytometry assays (Figure 3E). These indicate that IBV infection could significantly damage the phagocytic functions of macrophages.

\section{IBV M41 activated macrophage innate immunity}

Toll-like receptors (TLRs) are PRRs that detect characteristic microbial motifs to signal the presence of invading microbial organisms [24]. Among them, TLR3 and TLR7 recognize viral or non-viral RNA [25]. Myeloid differentiation factor 88 (MyD88) is a key linker molecule in the TLRs signaling pathway [26]. As is known, TLR3/7MyD88 are classic pathways involved in host recognition of viruses and innate immunity. In IBV-infected HD11 cells, the gene expressions of TLR7 and MyD88 both decreased at 12 hpi $(p<0.01)$. As the virus replicated, the gene expressions of TLR3/7 and MyD88 showed obvious upward trends $(p<0.01)$ and peaked at 36 hpi. The general expression trends of TLR3/7 and MyD88 in PBMCs-M $\phi$ were consistent with those of HD11 cells. In UV-IBV-treated HD11 cells, the gene expression of TLR3 decreased significantly at $12 \mathrm{hpi}(p<0.01)$, and MyD88 at 36 and 48 hpi $(p<0.01)$. In UV-IBV-treated PBMCs-M $\phi$, TLR7 and MyD88 gene expressions decreased at $12 \mathrm{hpi}$ $(p<0.01)$. TLR3 expression decreased at 24 and $48 \mathrm{hpi}$ $(p<0.01)$, and increased at $36 \mathrm{hpi}(p<0.01)$. However, the TLR3 up-regulation in UV-IBV-treated PBMCs-M $\phi$ was lower than that of IBV-infected cells (Figure 4A). These results indicate that viral replication is involved in IBV-induced TLR3/7-MyD88 modulation. By comparing the increasing mRNA expressions of TLR3 (HD11: sevenfold, PBMCs-M $\phi$ : 33-fold) and TLR7 (HD11: fourfold, PBMCs-M $\phi$ : 22-fold) at 36 hpi in IBV-infected cells, it can be concluded that IBV infection activates the TLR3/7 signaling pathways, especially the TLR3 signaling pathway.

Cytoplasmic retinoic acid-inducible gene I (RIG-I)-like receptors (RLRs) identify viral RNAs and initiate innate immune responses [27]. Chickens do not have RIG-I [28]. Therefore, the other RLR member, melanoma differentiation associated protein 5 (MDA5), plays an important role in recognizing intracellular viruses in chickens [29]. In IBV-infected HD11 cells, MDA5 expression decreased at $12 \mathrm{hpi}(p<0.01)$, then increased at 24,36 and $48 \mathrm{hpi}$ (24 and 36 hpi: $p<0.01,48$ hpi: $p<0.05$ ). The trend of MDA5 expression in PBMCs-M $\phi$ was consistent with that of HD11 cells, which increased at 12, 24 and 36 hpi $(p<0.01)$, and peaked at $24 \mathrm{hpi}$. In UV-IBV-treated HD11 cells and PBMCs-M $\phi$, the gene expression of MDA5 decreased at 12 and 24 hpi $(p<0.01$, Figure $4 \mathrm{~A})$.

These results suggest that IBV activates antiviral innate immunity pathways in macrophages. However, immunosuppression might occur at the early stage of IBV infection.

\section{IBV M41 upregulated IFN expressions in macrophages}

IFNs, including type I (IFN- $\alpha$ and IFN- $\beta$ ) and type II (IFN- $\gamma$ ), play important roles in antiviral defense, inhibit viral replication and work as immune effectors/modulators [30, 31]. In IBV-infected HD11 cells, the expressions of IFN- $\alpha$ and IFN- $\beta$ increased at 12 hpi $(p<0.01)$, while the expression of IFN- $\gamma$ decreased $(p<0.01)$. As the virus replicated, IFNs expressions showed upward trends, increasing at 24,36 , and $48 \mathrm{hpi}(p<0.01)$, and peaking at $36 \mathrm{hpi}$. The IFNs expression trends of PBMCs-M $\phi$ were consistent with those of HD11 cells. In UV-IBV-treated HD11 cells, the expression of IFN- $\alpha$ decreased at 36 and $48 \mathrm{hpi}(p<0.01)$, IFN- $\beta$ decreased at 12,24 and 36 hpi $(p<0.01)$, and IFN- $\gamma$ decreased at 24 hpi $(p<0.01)$. In UV-IBV-treated PBMCs-M $\phi$, IFN- $\alpha$ and IFN- $\gamma$ expressions decreased at 36 and $24 \mathrm{hpi}$, respectively $(p<0.01)$. However, IFN- $\beta$ expression increased at 36 hpi $(p<0.01$, Figure 4A).

These results indicate that IBV could activate IFNs production in macrophages, which has a relationship with viral replication. Comparing the increasing expressions of IFNs, IFN- $\alpha$ up-regulations (HD11: 490-fold, PBMCs-M $\phi$ : 49-fold) were the highest.

\section{IBV M41 activated macrophage acquired immunity}

Major histocompatibility complex (MHC) is a family of cell surface molecules, including MHC class I and II, which is involved in antigen presentation and activation of $\mathrm{T}$ cells [32]. Fc receptor is involved in receptormediated antibody-dependent internalization of immune complexes destined for intracellular degradation [33]. In IBV-infected HD11 cells, MHCII expression decreased at $12 \mathrm{hpi}(p<0.05)$. As the virus replicated, elevated expressions of MHC molecules and Fc receptors appeared at 24 and 36 hpi $(p<0.01)$, and peaked at 36 hpi. The expression trends of $\mathrm{MHC}$ molecules and Fc receptor in PBMC-M $\phi$ were consistent with those of HD11 cells. In IBV-infected PBMCs-M $\phi$, MHC molecules and Fc receptor expressions were up-regulated, but MHCII expression decreased at $24 \mathrm{hpi}(p<0.01)$. In the UV-IBV-treated HD11 cells, only MHCII expression increased at $12 \mathrm{hpi}$ $(p<0.01$, Figure 4B).

Scavenger receptors and mannose receptors, parts of PRRs, are also involved in pathogen elimination. CD36 is a scavenger receptor involved in immunity, metabolism and angiogenesis [34]. Mannose receptor, MARCO, 
A
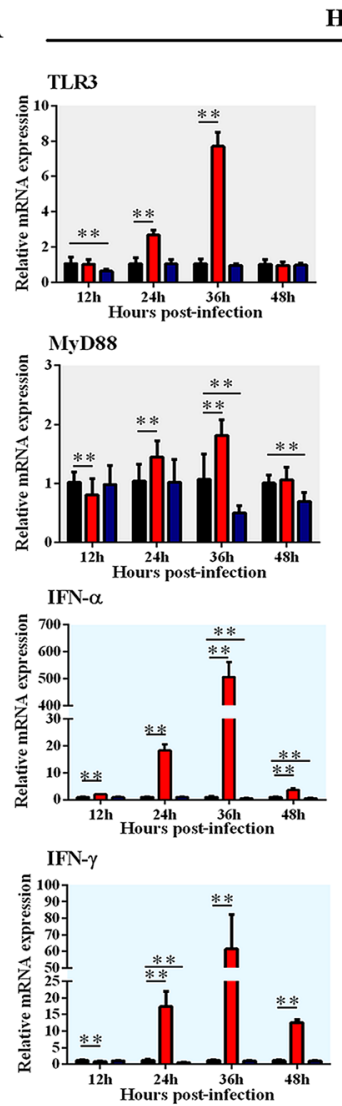

B

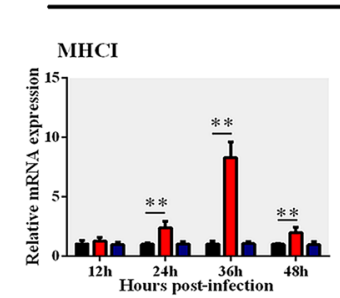

Fc receptor

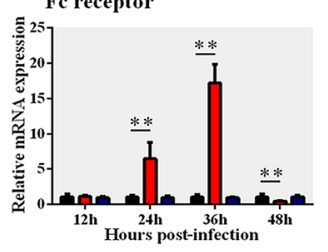

MARCO

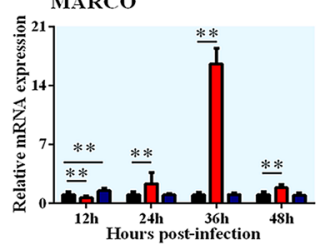

HD11

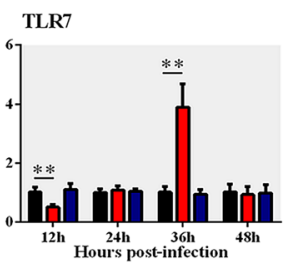

MDA5

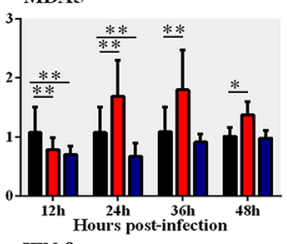

IFN- $\beta$

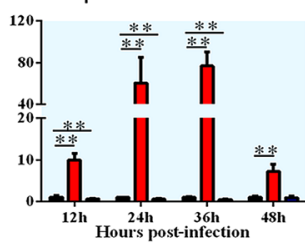

Mock

IBV

UV-IBV

HD11
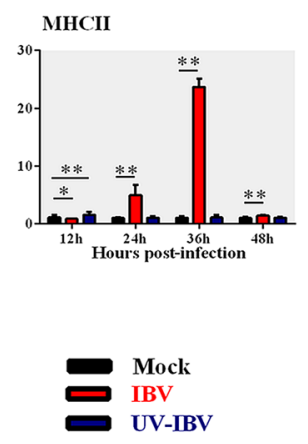

CD36

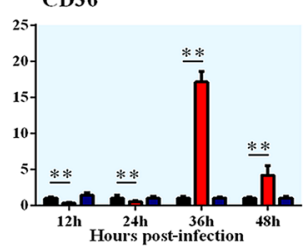

Figure 4 Antiviral innate and acquired immunity-related gene expressions. A Antiviral innate immunity-related factors mRNA expressions. Relative mRNA expressions of TLRs (TLR3, TLR7), MyD88, MDA5, IFNs (IFN-a, IFN- $\beta$, IFN- $\gamma$ ) in IBV-infected, UV-IBV-treated cells and Mock cells were detected by qRT-PCR method. $\beta$-actin acted as a reference gene. B Acquired immunity-related gene mRNA expressions. Relative mRNA expressions of $\mathrm{MHC}$ molecules (MHCI, MHCII), FC receptor, MARCO, CD36 in IBV-infected, UV-IBV-treated cells and Mock cells were detected by qRT-PCR method. $\beta$-actin acted as a reference gene. Data presented as mean \pm SD $(n=3)$. * means the significance of between IBV-infected or UV-IBV-treated cells with Mock cells. * means $p<0.05,{ }^{* *}$ means $p<0.01$. 
plays a role in pathogen clearance and inflammatory ligand recognition [35]. In IBV-infected HD11 cells, the expressions of MARCO decreased at $12 \mathrm{hpi}$ significantly $(p<0.01)$, and CD36 at 12, and $24 \mathrm{hpi}(p<0.01)$. Increased expressions of both genes appeared and peaked at $36 \mathrm{hpi}$ $(p<0.01)$. The expression trends of MARCO and CD36 in PBMC-M $\phi$ were similar to those in HD11 cells. Both MARCO and CD36 expressions down-regulated at 12 hpi $(p<0.01)$, and then increased and peaked at $36 \mathrm{hpi}$ $(p<0.01)$. For the UV-IBV-treated HD11 cells, there were no distinct changes in the two kinds of cell (Figure 4B).

These results indicate that IBV inhibits the ability of macrophages to eliminate pathogen and antigen presentation at the early stage of viral infection, but do not affect the latter activation of acquired immunity. Among these genes, the expression of MHCII was the highest (23-fold) compared with other genes in IBV-infected HD11 cells, and MHCII (26-fold) and Fc receptor (67-fold) in IBVinfected PBMCs-M $\phi$, showing that IBV infection mainly activates MHCII and Fc receptors.

\section{IBV M41 activated macrophage chemokine expressions}

Chemokines are involved in host immune responses and inflammatory processes [36, 37]. Macrophage migration inhibitory factor (MIF), CCL4 (also known as mac-

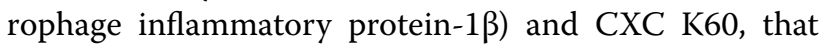
can activate macrophages and $\mathrm{T}$ cells, are involved in cell migration, and promote cell maturation [38-40]. In IBVinfected HD11 cells, the gene expressions of MIF, CCL4 and CXC K60 up-regulated significantly $(p<0.01)$, and peaked at $24 \mathrm{hpi}$, but there was a marked decrease of MIF expression at $12 \mathrm{hpi}(p<0.01)$. The expression trends in PBMCs-M $\phi$ were similar to those in HD11 cells. In UVIBV-treated HD11 cells, CCL4 expression decreased at 12 hpi $(p<0.01)$ and CXC K60 decreased at $12(p<0.01)$ and 36 hpi $(p<0.05)$. In UV-IBV-treated PBMCs-M $\phi$, the decreased expression of MIF showed at $36 \mathrm{hpi}(p<0.01)$, CCL4 decreased at 24 and 36 hpi $(p<0.01)$, and CXCK60 decreased at 36 hpi $(p<0.01$, Figure 5A).

XCL1 (also known as lymphotactin) and CXCL12 (also known as stromal cell derived factor-1) have a strong chemotactic effect on lymphocytes, involved in inflammatory responses [41, 42]. In IBV-infected HD11 cells, there was an abrupt increase in XCL1 and CXCL12 expressions at 24 hpi $(p<0.01)$. However, XCL1 and CXCL12 expressions decreased significantly at 12 and $48 \mathrm{hpi}$, respectively $(p<0.01)$. The XCL1 and CXCL12 expression trends in PBMCs-M $\phi$ were similar to those in HD11 cells $(p<0.01)$, but there was a gradual decrease of XCL1 and CXCL12 expressions at 36 hpi $(p<0.01)$. In the UV-IBV-treatment experiment, there were only increased expressions of CXCL12 in HD11 cells $(p<0.05)$ and of XCL1 in PBMCs-M $\phi$ at 12 hpi $(p<0.01$, Figure 5A).

These results suggest that IBV could activate the chemotaxis in macrophages with temporary suppression at the early stage of infection. The mRNA expressions of CCL4 (29-fold) and MIF (24-fold) were the highest in IBVinfected HD11 cells compared with other chemokines, indicating that IBV-infected macrophages mainly secrete CCL4 and MIF.

\section{IBV M41 up-regulated inflammatory factor expressions in macrophages}

Interleukin (IL)-1 $\beta$, IL-6 and tumor necrosis factor (TNF)- $\alpha$ are classic pro-inflammatory cytokines and activate a variety of stress responses [43-45]. Transcription factor Nuclear factor- $\mathrm{kB}(\mathrm{NF}-\mathrm{\kappa} B)$ is a redox-sensitive transcription factor and modulates ILs production [46]. Inducible nitric oxide synthase (iNOS) is involved in NO synthesis and the pro-inflammatory responses of macrophages [47]. IL-10 is an anti-inflammatory cytokine which controls antigen presentation function and the ability to synthesize cytokines [48]. Peroxisome proliferator-activated receptor (PPAR) $\gamma$ is related to inflammation inhibition [49, 50]. In IBV-infected HD11 cells, pro-inflammatory cytokines showed upward trends from 12 to 24 hpi. IL-1 $\beta$, IL-6, TNF- $\alpha$, iNOS peaked at 24 hpi $(p<0.01)$, and NF-kB peaked at 36 hpi $(p<0.01)$. The expression trends in $\mathrm{PBMCs}-\mathrm{M} \phi$ were similar to those in HD11 cells. For anti-inflammatory cytokines, IL-10 decreased at 12 hpi in IBV-infected HD11 cells $(p<0.01)$, and PPAR- $\gamma$ was up-regulated at 24,36 , and 48 hpi $(p<0.01)$. However, in PBMCs-M $\phi$, there was an obvious increase in IL-10 expression at 24, 36, and $48 \mathrm{hpi}$ $(p<0.01)$, and in PPAR- $\gamma$ at 24 hpi $(p<0.01)$, respectively (Figure 5B).

These results indicate that IBV induces macrophage pro-inflammatory and anti-inflammatory responses. In IBV infection, there were increased expressions of IL-6 mRNA (27-fold) in HD11 cells. The relative mRNA expression of IL-1 $\beta$ (246-fold), IL-6 (1560-fold), iNOS mRNA (118-fold) in PBMCs-M $\phi$ had higher expressions compared with other cytokines.

\section{IBV M41 induced autophagy in macrophages}

Microtubule-associated protein 1 light chain 3 II (LC3II) is an autophagic target protein involved in the formation of autophagosomes [51]. Mammalian target of rapamycin (mTOR) and Beclin-1 are key proteins involved in the autophagic pathways [52, 53]. LC3II expression peaked at 36 hpi in IBV-infected HD11 cells and PBMCs-M $\phi$ $(p<0.01)$. mTOR and Beclin-1 increased to a peak at 24 or 36 hpi $(p<0.01)$, and subsequently decreased rapidly 
A

A
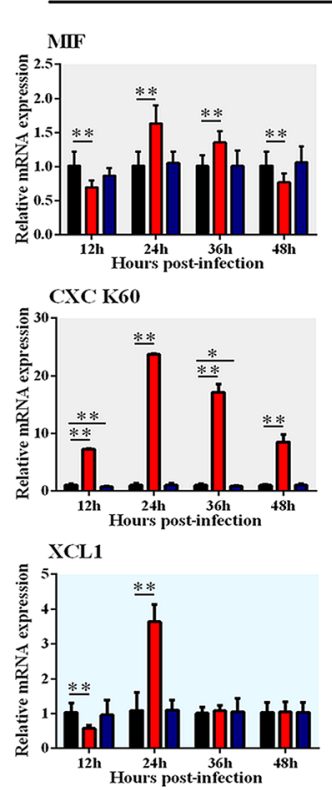

HD11
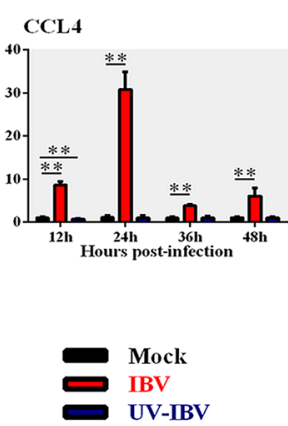

CXCL12

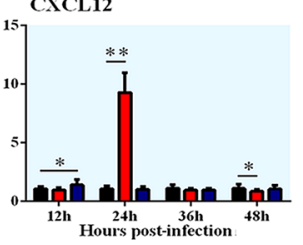

HD11

B
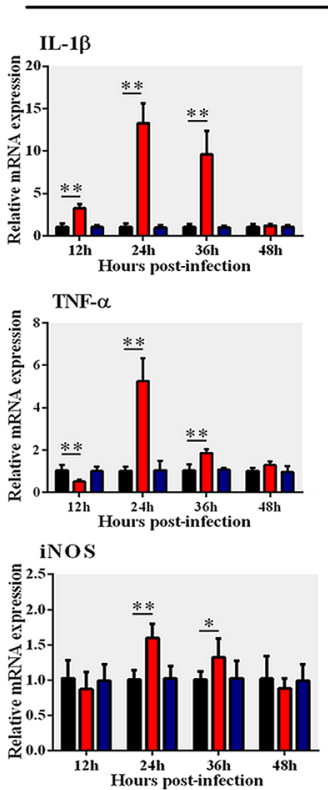

IL-10

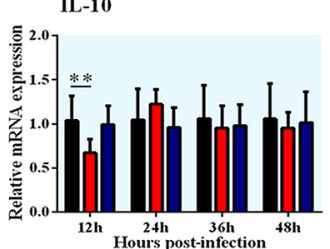

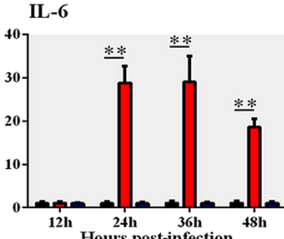

NF-кB

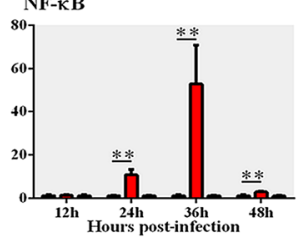

IBV
UV-IBV
Mock

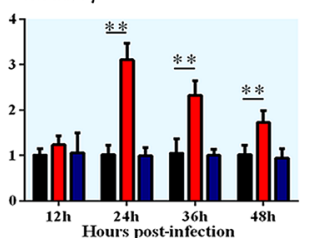

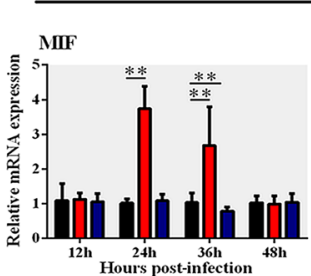

CXC K60
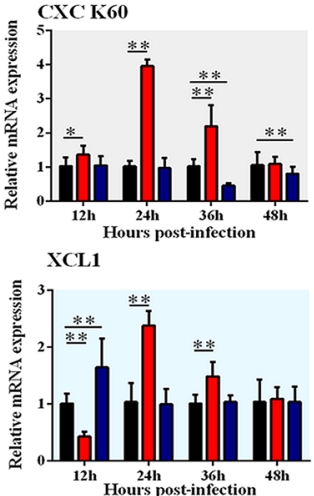

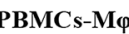

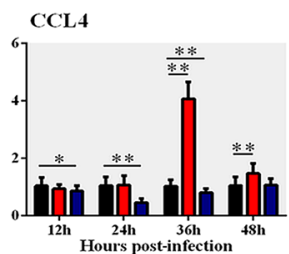

Mock
IBV
UV-IBV

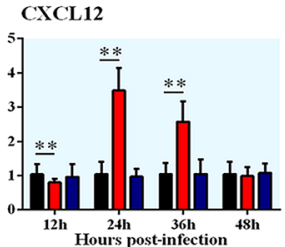

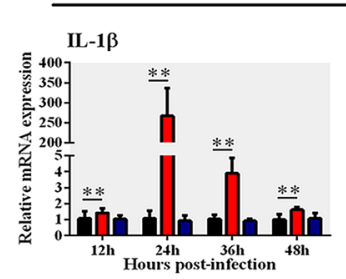

IL-6

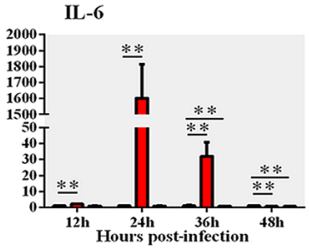

TNF- $\alpha$
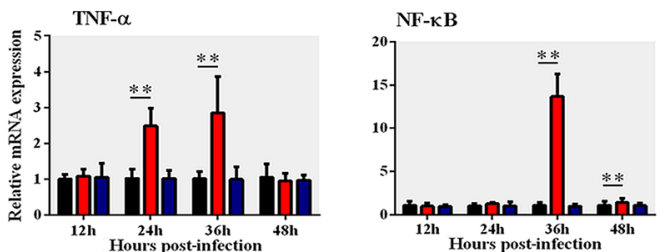

inOs

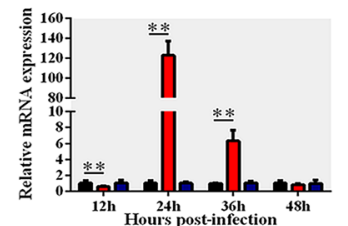

IL-10
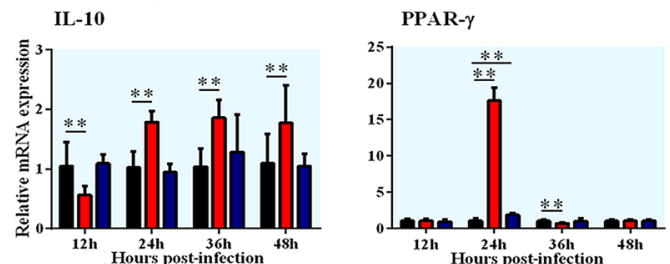

Figure 5 Chemokines and inflammatory factors gene expressions. A Chemokine mRNA expressions. Relative mRNA expressions of MIF, CCL4, CXC K60, XCL-1, CXCL12 in IBV-infected, UV-IBV-treated cells and Mock cells were detected by qRT-PCR method. $\beta$-actin acted as a reference gene. B Inflammatory factor mRNA expressions. Relative mRNA expressions of IL-1 $\beta$, IL-6, NF-KB, TNF-a, iNOS, IL-10 and PPAR- $\gamma$ in IBV-infected, UV-IBV-treated cells and Mock cells were detected by qRT-PCR method. $\beta$-actin acted as a reference gene. Data presented as mean $\pm S D(n=3) .{ }^{*}$ means the significance of between IBV-infected or UV-IBV-treated cells with Mock cells. ${ }^{*}$ means $p<0.05$, ${ }^{* *}$ means $p<0.01$. 


\section{A}
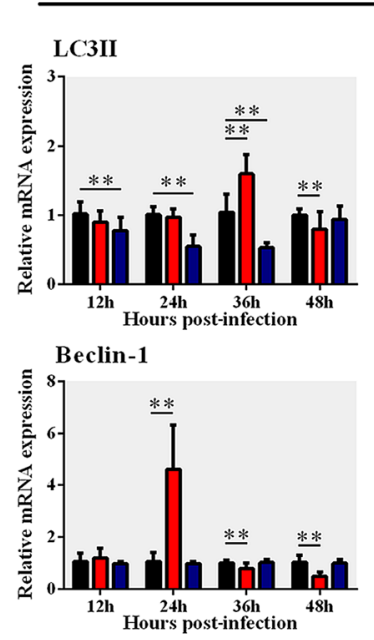

B
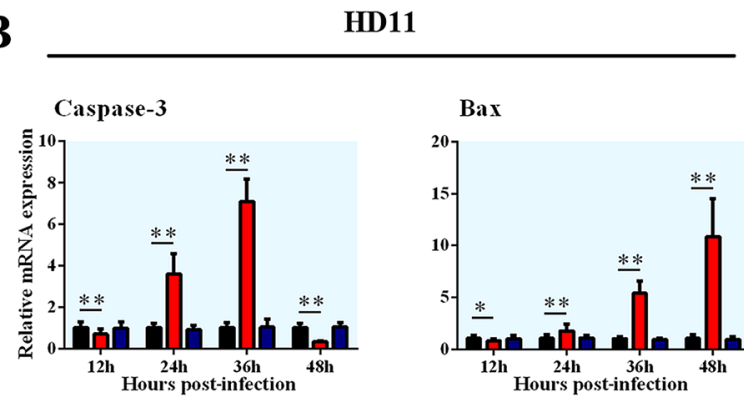

Bcl-2
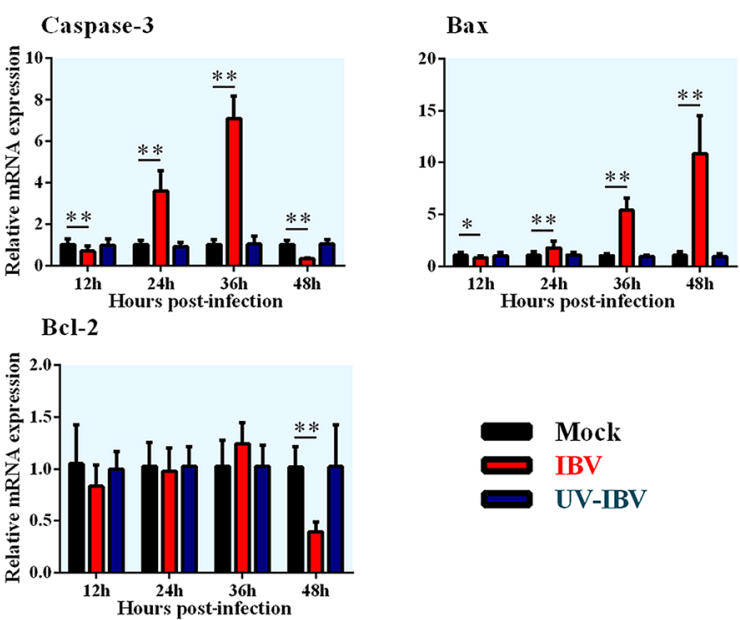
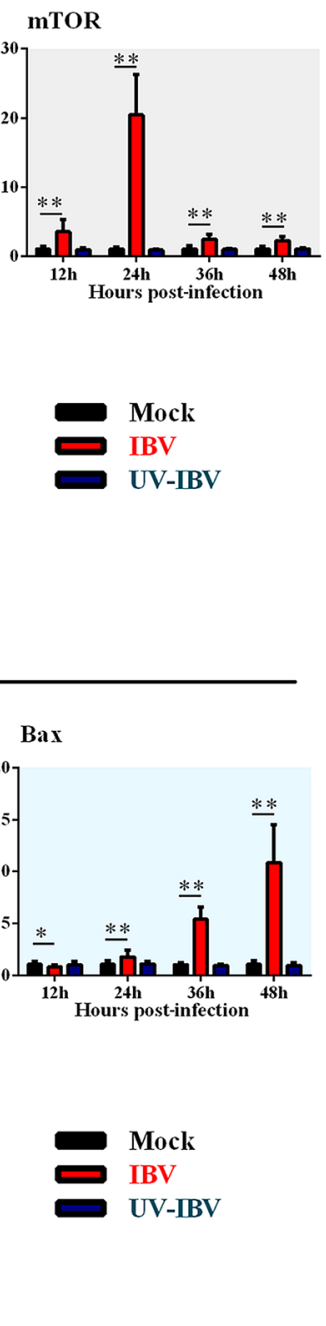

\section{PBMCs-M $\varphi$}
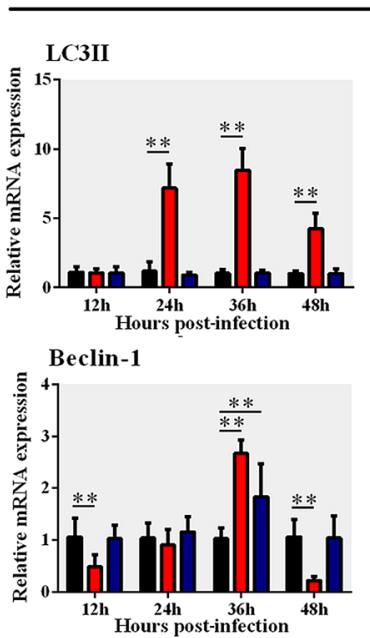

PBMCs-M $\varphi$
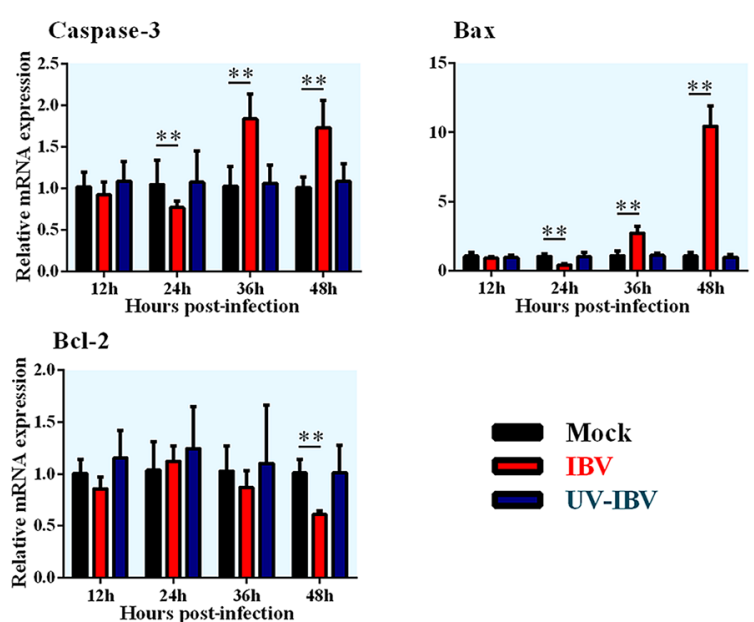
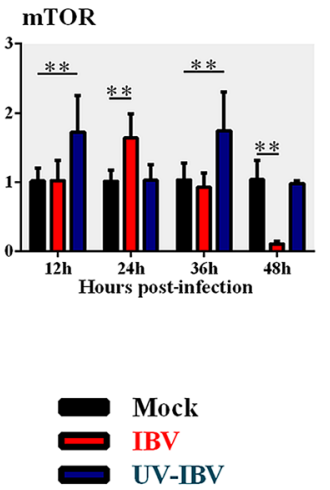

UV-IBV

Figure 6 Gene expressions of related proteins in apoptosis and autophagy. A Autophagy-related gene mRNA expressions. Relative mRNA expressions of LC3II, mTOR and Beclin-1 in IBV-infected, UV-IBV-treated cells and Mock cells were detected by qRT-PCR method. $\beta$-actin acted as a reference gene. B Apoptosis-related gene mRNA expressions. Relative mRNA expressions of Caspase-3, Bax, BCl-2 in IBV-infected, UV-IBV-treated cells and Mock cells were detected by qRT-PCR method. $\beta$-actin acted as a reference gene. Data presented as mean $\pm S D(n=3)$. ${ }^{*}$ means the significance of between IBV-infected or UV-IBV-treated cells with Mock cells. ${ }^{*}$ means $p<0.05,{ }^{* *}$ means $p<0.01$.

in IBV-infected HD11 cells and PBMCs-M $\phi$, respectively (Figure 6A). This indicates that IBV infection could induce autophagy at the middle term of viral replication and participate in the disease pathogenic process.

\section{IBV M41 induced apoptosis in macrophages}

Caspase-3 is an executive factor of apoptosis [54]. Bcl2-associated X (Bax) is a classic pro-apoptotic factor [55]. $\mathrm{Bcl}-2$ is an inhibitor of apoptosis [56]. Caspase-3 expression peaked at 36 hpi in IBV-infected HD11 cells and PBMCs-M $\phi(p<0.01)$. However, Caspase-3 expression was down-regulated at 12 and $48 \mathrm{hpi}$ in IBV-infected HD11 cells $(p<0.01)$, and at 24 hpi in PBMCs-M $\phi$ $(p<0.01)$, respectively. In IBV-infected HD11 cells, the expression of Bax decreased at $12 \mathrm{hpi}(p<0.05)$, and 24 hpi in PBMCs-M $\phi(p<0.01)$. As the virus replicated, the expression of Bax showed an increase trend, and peaked at 48 hpi $(p<0.01)$. Remarkably, decreased expressions of Bcl-2 appeared in both HD11 cells and PBMCs-M $\mathrm{M}$ at 48 hpi $(p<0.01)$. UV-IBV treatment did not change the mRNA expressions of Caspase- 3 , Bax and Bcl-2 in macrophages (Figure 6B). These results indicate that viral 
replication provokes apoptosis in macrophages at the late stage of infection.

\section{Discussion}

Macrophages are an important part of innate immunity [57]. Macrophages respond to external stimuli with rapid changes in their expressions of various related genes. In this study, we established an experimental model of IBV infection of macrophages. The high-purity HD11 cells (99.8\%) and PBMCs-M $\Phi$ (91.3\%) could exhibit typical CPE at $36 \mathrm{~h}$ post-IBV M41 strain infection, and the virus could replicate on them. These results demonstrated that both kinds of cell were suitable for studying the interaction of IBV and macrophages and the underlying mechanisms. Macrophage viability and abilities were checked. IBV could affect macrophage viability and damage their phagocytic functions, which are related to viral replication. Han et al. [58] found that IBV Beaudette strain could propagate stably in HD11 cells and the virus titer reached the high level of $10^{6.85} \mathrm{TCID}_{50} / \mathrm{mL}$, typical CPE appeared at $36 \mathrm{hpi}$, and cell viability decreased obviously at the same time. In other words, IBV could impair the viability of chicken macrophages and their biological functions, which was consistent with our results.

Host immune response is divided into innate immunity and acquired immunity [59]. TLRs and RLRs are two types of PRR in the innate immune system [60]. TLR3 and TLR7 are both involved in IBV infection, which is consistent with previous studies $[16,61]$, and TLR3 may play a key role in IBV-induced viral immune mechanisms. Furthermore, IBV infection activates MDA5 expression $[16,62]$. The expressions of the key antiviral molecules, IFNs and other acquired immunity-related genes, which are involved in antigen presentation and pathogen clearance, increased significantly with virus replication. This indicates that IBV activates the innate immune response of macrophages. Interestingly, the gene expressions of certain signal proteins, such as TLR7, MyD88, MDA5, MHCII, and Fc receptor, decreased in HD11 cells and PBMCs-M $\phi$ at $12 \mathrm{hpi}$, respectively, indicating that IBV could inhibit the immune regulatory function of macrophages at the early stage of its infection.

Macrophages secrete chemokines post-IBV infection, which attract immune competent cells to the sites of infection and inflammation [63]. Meanwhile, cytokines are activated to participate in information transmission, immune regulation and effector functions [43, 44]. Similar to other research, we found that IBV activated the gene expressions of most chemokines and inflammatory cytokines $[16,61,64]$, demonstrating a promotion of inflammatory response. Among them, CCL4, IL-1 $\beta$, IL- 6 , and iNOS mainly activated and participated in innate immunity of IBV infection. The expressions of
MIF, XCL1 and CXCL12 decreased at the early stage of infection, indicating IBV affects macrophage chemotaxis. Moreover, the up-regulation of inflammatory cytokines in IBV infection was higher in percentage terms than in anti-inflammatory cytokines at 12 and $24 \mathrm{hpi}$, indicating that a pro-inflammatory response is activated at the early stage of IBV infection. From 24 to $48 \mathrm{hpi}$, the expressions of cytokines gradually decreased, indicating that at the late stage of IBV infection, an anti-inflammatory response is dominant in the macrophages.

Finally, the gene expressions of related proteins involved in apoptosis and autophagy were investigated. There have been reports that IBV could induce autophagy and apoptosis in both chicken and mammalian cells $[58,65,66]$. In this study, there occurred autophagy and apoptosis in HD11 cells and PBMCs-M $\phi$ post-IBV infection. In addition, we found that autophagy appeared and peaked at the period of extensive viral replication, and apoptosis occurred obviously at the later stage of stable virus replication. With virus replication in macrophages, there appeared autophagy firstly and apoptosis subsequently. Furthermore, the gene expression levels of related proteins enhanced post-IBV infection, while there were no obvious changes post-UV-IBV treatment. This further supports the fact that the up-regulation of gene expressions has a close relationship with virus replication.

In conclusion, IBV decreased macrophage phagocytic functions and viability, but strengthened pathogen elimination functions. IBV promoted nearly all the gene expressions of related proteins in macrophagesexcept some degree of suppression at the earlier stageto exert its biofunctions in multiple host responses, and the dynamic changes of gene expression had a close relationship with virus replication. This might provide some insight into understanding the immunopathogenesis mechanism of IBV infection.

\section{Abbreviations \\ IBV: Infectious bronchitis virus; UV-IBV: UV-inactivated IBV; PAMP: Pathogen- associated molecular pattern; PRRs: Pattern recognition receptors; PBMCs-M $\varphi$ : Peripheral blood mononuclear cells-derived macrophages; SPF: Specific- pathogen-free; MOI: Multiplicity of infection; CPE: Cytopathic effects; $\mathrm{TCID}_{50}$ : 50\% Tissue culture infective dose; NO: Nitric oxide; qRT-PCR: Quantitative real-time polymerase chain reaction; hpi: Hours post-infection; MHC: Major histocompatibility complex; TLRs: Toll-like receptors; MyD88: Myeloid dif- ferentiation factor 88; MDA5: Melanoma differentiation associated protein 5; IFNs: Interferons; MIF: Macrophage migration inhibitory factor; iNOS: Inducible nitric oxide synthase; IL: Interleukin; NF-kB: Nuclear factor KB; TNF-a:Tumor necrosis factor- $\alpha$; PPAR- $\gamma$ : Proliferator-activated receptor $\gamma ;$ mTOR: Mammalian target of rapamycin; LC3II: Microtubules associated protein 1 light chain 3 I; Bax: Bcl-2-associated X.}

\section{Acknowledgements}

The first author Xiaoqi Sun thanks Dr Yicong Chang of the College of Veterinary Medicine (Northeast Agricultural University, Harbin, China) for his support and assistance during her study and life. 


\section{Authors' contributions}

GL supervised the whole experiments. XS performed the practical work and completed the experiments, ZW, CS, JY, HL, HC, LL, YR, XH and RZ provided help during the experiments. XW helped to revise the manuscript. All authors read and approved the final manuscript.

\section{Funding}

This work was supported by the National Natural Science Foundation of China (Grant Numbers 31172295, 31272569).

\section{Availability of data and materials}

The datasets used and/or analysed during the current study are available from the corresponding author upon reasonable request.

\section{Ethics approval and consent to participate}

The Institutional Animal Care and Use Committee of Northeast Agricultural University (Harbin, Heilongjiang Province) approved the experimental procedures in the present study (SYXK (Hei) 2012-2067).

\section{Competing interests}

The authors declare that they have no competing interests.

\section{Author details \\ 1 Department of Basic Veterinary Science, College of Veterinary Medicine, Heilongjiang Key Laboratory for Animal and Comparative Medicine, Northeast Agricultural University, Harbin 150030, China. ${ }^{2}$ Large Scale Instrument and Equipment Sharing Service Platform, Northeast Agricultural University, Harbin 150030, China. ${ }^{3}$ State Key Laboratory of Veterinary Biotechnology, Harbin Veterinary Research Institute, Chinese Academy of Agricultural Science, Harbin 150069, China. ${ }^{4}$ Department of Computer Science and Technology, College of Electrical and Information Technology, Northeast Agricultural University, Harbin 150030, China.}

Received: 25 August 2020 Accepted: 6 January 2021

Published online: 28 January 2021

\section{References}

1. Cavanagh D (2007) Coronavirus avian infectious bronchitis virus. Vet Res 38:281-297. https://doi.org/10.1051/vetres:2006055

2. Brierley I, Boursnell ME, Binns MM, Bilimoria B, Blok VC, Brown TD, Inglis SC (1987) An efficient ribosomal frame-shifting signal in the polymeraseencoding region of the coronavirus IBV. EMBO J 6:3779-3785

3. Cook JKA, Jackwood M, Jones RC (2012) The long view: 40 years of infectious bronchitis research. Avian Pathol 41:239-250

4. Cavanagh D, Davis PJ, Cook JKA (1992) Infectious bronchitis virus: evidence for recombination within the Massachusetts serotype. Avian Pathol 21:401-408. https://doi.org/10.1080/03079459208418858

5. Cavanagh D, Davis PJ, Mockett APA (1988) Amino acids within hypervariable region 1 of avian coronavirus IBV (Massachusetts serotype) spike glycoprotein are associated with neutralization epitopes. Virus Res 11:141-150. https://doi.org/10.1016/0168-1702(88)90039-1

6. de Wit JJS, Malo A, Cook JKA (2019) Induction of IBV strain-specific neutralizing antibodies and broad spectrum protection in layer pullets primed with IBV Massachusetts (Mass) and 793B vaccines prior to injection of inactivated vaccine containing Mass antigen. Avian Pathol 48:135-147. https://doi.org/10.1080/03079457.2018.1556778

7. Parsons LM, Bouwman KM, Azurmendi H, de Vries RP, Cipollo JF, Verheije $\mathrm{MH}$ (2019) Glycosylation of the viral attachment protein of avian coronavirus is essential for host cell and receptor binding. J Biol Chem 294:7797-7809. https://doi.org/10.1074/jbc.RA119.007532

8. Kusters JG, Niesters HG, Lenstra JA, Horzinek MC, van der Zeijst BA (1989) Phylogeny of antigenic variants of avian coronavirus IBV. Virology 169:217-221. https://doi.org/10.1016/0042-6822(89)90058-5

9. Dolz R, Pujols J, Ordonez G, Porta R, Majo N (2008) Molecular epidemiology and evolution of avian infectious bronchitis virus in Spain over a fourteen-year period. Virology 374:50-59. https://doi.org/10.1016/j.virol .2007.12.020

10. Chen R, Zeng L, Zhu S, Liu J, Zeh HJ, Kroemer G, Wang H, Billiar TR, Jiang J, Tang D, Kang R (2019) CAMP metabolism controls caspase-11 inflammasome activation and pyroptosis in sepsis. Sci Adv. https://doi. org/10.1126/sciadv.aav5562

11. Taylor PR, Martinez-Pomares L, Stacey M, Lin HH, Brown GD, Gordon S (2005) Macrophage receptors and immune recognition. Annu Rev Immunol 23:901-944. https://doi.org/10.1146/annurev.immunol.23.02170 4.115816

12. Wadsworth SA, Cavender DE, Beers SA, Lalan P, Schafer PH, Malloy EA Wu W, Fahmy B, Olini GC, Davis JE, Pellegrino-Gensey JL, Wachter MP, Siekierka JJ (1999) RWJ 67657, a potent, orally active inhibitor of p38 mitogen-activated protein kinase. J Pharmacol Exp Ther 291:680-687. https://doi.org/10.1016/j.ejphar.2010.01.011

13. Lee JW, Kim NH, Kim JY, Park JH, Shin SY, Kwon YS, Lee HJ, Kim SS, Chun W (2013) Aromadendrin inhibits lipopolysaccharide-induced nuclear translocation of NF-kappaB and phosphorylation of JNK in RAW 264.7 Macrophage Cells. Biomol Ther (Seoul) 21:216-221. https://doi.org/10.4062/ biomolther.2013.023

14. Majewska M, Szczepanik M (2006) The role of Toll-like receptors (TLR) in innate and adaptive immune responses and their function in immune response regulation. Postepy Hig Med Dosw 60:52-63. https://doi. org/10.4049/jimmunol.1101640

15. Xaus J, Cardo M, Valledor AF, Soler C, Lloberas J, Celada A (1999) Interferon gamma induces the expression of p21 waf- 1 and arrests macrophage cell cycle, preventing induction of apoptosis. Immunity 11:103-113. https:// doi.org/10.1016/s1074-7613(00)80085-0

16. Kameka AM, Haddadi S, Kim DS, Cork SC, Abdul-Careem MF (2014) Induction of innate immune response following infectious bronchitis corona virus infection in the respiratory tract of chickens. Virology 450-451:114121. https://doi.org/10.1016/j.virol.2013.12.001

17. Lee KW, Li G, Lillehoj HS, Lee SH, Jang SI, Babu US, Lillehoj EP, Neumann AP, Siragusa GR (2011) Bacillus subtilis-based direct-fed microbials augment macrophage function in broiler chickens. Res Vet Sci 91:e87-91. https://doi.org/10.1016/j.rvsc.2011.01.018

18. Guabiraba R, Garrido D, Bailleul G, Trotereau A, Pinaud M, Lalmanach AC, Chanteloup NK, Schouler C (2017) Unveiling the participation of avian kinin ornithokinin and its receptors in the chicken inflammatory response. Vet Immunol Immunopathol 188:34-47. https://doi. org/10.1016/j.vetimm.2017.04.005

19. Wang $X$, Zhao J, Tang S, Ye Z, Hewlett I (2010) Viremia associated with fatal outcomes in ferrets infected with avian H5N1 influenza virus. PLoS ONE 5:e12099. https://doi.org/10.1371/journal.pone.0012099

20. Cao J, Chen X, Jiang L, Lu B, Ying M (2020) DJ-1 suppresses ferroptosis through preserving the activity of S-adenosyl homocysteine hydrolase. Nat Commun 11:1251. https://doi.org/10.1038/s41467-020-15109-y

21. Yuan G, Zhou X, Gong Z, Zhang P, Sun X, Zheng S (2006) Expression and activity of inducible nitric oxide synthase and endothelial nitric oxide synthase correlate with ethanolinduced liver injury. World J Gastroenterol 12:2375-2381. https://doi.org/10.3748/wjg.v12.i15.2375

22. Livak KJ, Schmittgen TD (2001) Analysis of relative gene expression data using real-time quantitative PCR and the 2(-Delta Delta C(T)) Method. Methods 25:402-408. https://doi.org/10.1006/meth.2001.1262

23. MacMicking J, Xie QW, Nathan C (1997) Nitric oxide and macrophage function. Annu Rev Immunol 15:323-350. https://doi.org/10.1146/annur ev.immunol.15.1.323

24. Fonceca AM, Zosky GR, Bozanich EM, Sutanto EN, Kicic A, McNamara PS, Knight DA, Sly PD, Turner DJ, Stick SM (2018) Accumulation mode particles and LPS exposure induce TLR-4 dependent and independent inflammatory responses in the lung. Respir Res 19:15. https://doi.org/10.1186/ s12931-017-0701-z

25. Lin Y, Ren L, Wang W, Di J, Zeng S, Saito S (2009) Effect of TLR3 and TLR7 activation in uterine NK cells from non-obese diabetic (NOD) mice. J Reprod Immunol 82:12-23. https://doi.org/10.1016/j.jri.2009.03.004

26. Yamamoto M, Sato S, Hemmi H, Uematsu S, Hoshino K, Kaisho T, Takeuchi O, Takeda K, Akira S (2003) TRAM is specifically involved in the Toll-like receptor 4-mediated MyD88-independent signaling pathway. Nat Immunol 4:1144-1150. https://doi.org/10.1038/ni986

27. Mukherjee K, Korithoski B, Kolaczkowski B (2014) Ancient origins of vertebrate-specific innate antiviral immunity. Mol Biol Evol 31:140-153. https://doi.org/10.1093/molbev/mst184

28. Lee C-C, Tung C-Y, Wu CC, Lin TL (2019) Avian innate immunity with an emphasis on chicken melanoma differentiation-associated gene 5 
(MDA5). Taiwan Veterinary J 45:43-55. https://doi.org/10.1142/S1682 648519300016

29. Lazear HM, Pinto AK, Ramos HJ, Vick SC, Shrestha B, Suthar MS, Gale M $\mathrm{Jr}$, Diamond MS (2013) Pattern recognition receptor MDA5 modulates CD8+ T cell-dependent clearance of West Nile virus from the central nervous system. JVirol 87:11401-11415. https://doi.org/10.1128/ JVI.01403-13

30. Echebli N, Tchitchek N, Dupuy S, Bruel T, Peireira Bittencourt Passaes C, Bosquet N, Le Grand R, Bourgeois C, Favier B, Cheynier R, Lambotte O, Vaslin B (2018) Stage-specific IFN-induced and IFN gene expression reveal convergence of type I and type II IFN and highlight their role in both acute and chronic stage of pathogenic SIV infection. PLOS ONE 13:e0190334. https://doi.org/10.1371/journal.pone.0190334

31. Ivashkiv LB (2018) IFNgamma: signalling, epigenetics and roles in immunity, metabolism, disease and cancer immunotherapy. Nat Rev Immunol 18:545-558. https://doi.org/10.1038/s41577-018-0029-z

32. Roche PA, Furuta K (2015) The ins and outs of MHC class II-mediated antigen processing and presentation. Nat Rev Immunol 15:203-216. https:// doi.org/10.1038/nri3818

33. Sapinoro R, Volcy K, Rodrigo WW, Schlesinger JJ, Dewhurst S (2008) Fc receptor-mediated, antibody-dependent enhancement of bacteriophage lambda-mediated gene transfer in mammalian cells. Virology 373:274-286. https://doi.org/10.1016/j.virol.2007.12.013

34. Febbraio M, Hajjar DP, Silverstein RL (2001) CD36: a class B scavenger receptor involved in angiogenesis, atherosclerosis, inflammation, and lipid metabolism. J Clin Invest 108:785-791. https://doi.org/10.1172/JCl14 006

35. Mukhopadhyay S, Varin A, Chen Y, Liu B, Tryggvason K, Gordon S (2011) SR-A/MARCO-mediated ligand delivery enhances intracellular TLR and NLR function, but ligand scavenging from cell surface limits TLR4 response to pathogens. Blood 117:1319-1328. https://doi.org/10.1182/ blood-2010-03-276733

36. Heydtmann M, Shields P, McCaughan G, Adams D (2001) Cytokines and chemokines in the immune response to hepatitis $C$ infection. Curr Opin Infect Dis 14:279-287. https://doi.org/10.1097/00001432-20010 6000-00006

37. Us D (2003) Chemokine receptors: Their roles in the pathogenesis of human immunodeficiency virus (HIV) and resistance to HIV infection. Mikrobiyol Bul 37:75-87

38. Flores M, Saavedra R, Bautista R, Viedma R, Tenorio EP, Leng L, Sanchez Y, Juarez I, Satoskar AA, Shenoy AS, Terrazas LI, Bucala R, Barbi J, Satoskar AR, Rodriguez-Sosa M (2008) Macrophage migration inhibitory factor (MIF) is critical for the host resistance against Toxoplasma gondii. FASEB J 22:3661-3671. https://doi.org/10.1096/f.08-111666

39. Hughes S, Bumstead N (2000) The gene encoding the chicken chemokine K60 maps to chromosome 4. Anim Genet 31:418-419. https ://doi.org/10.1046/j.1365-2052.2000.00697.x

40. Sun B, Lei Y, Cao Z, Zhou Y, Sun Y, Wu Y, Wang S, Guo W, Liu C (2019) TroCCL4, a CC chemokine of Trachinotus ovatus, is involved in the antimicrobial immune response. Fish Shellfish Immunol 86:525-535. https://doi. org/10.1016/j.fsi.2018.11.080

41. Razmkhah M, Talei AR, Doroudchi M, Khalili-Azad T, Ghaderi A (2005) Stromal cell-derived factor-1 (SDF-1) alleles and susceptibility to breast carcinoma. Cancer Lett 225:261-266. https://doi.org/10.1016/j.canle t.2004.10.039

42. Guzzo C, Fox J, Lin Y, Miao H, Cimbro R, Volkman BF, Fauci AS, Lusso P (2013) The CD8-derived chemokine XCL1/lymphotactin is a conformation-dependent, broad-spectrum inhibitor of HIV-1. PLoS Pathog 9:e1003852. https://doi.org/10.1371/journal.ppat.1003852

43. Woolley DE, Tetlow LC (2000) Mast cell activation and its relation to proinflammatory cytokine production in the rheumatoid lesion. Arthritis Res 2:65-74. https://doi.org/10.1186/ar70

44. Scheller J, Chalaris A, Schmidt-Arras D, Rose-John S (2011) The pro- and anti-inflammatory properties of the cytokine interleukin-6. Biochim Biophys Acta 1813:878-888. https://doi.org/10.1016/j.bbamcr.2011.01.034

45. Feldmann M, Maini RN (2001) Anti-TNF alpha therapy of rheumatoid arthritis: what have we learned? Annu Rev Immunol 19:163-196. https:// doi.org/10.1146/annurev.immunol.19.1.163

46. Karin M, Ben-Neriah Y (2000) Phosphorylation meets ubiquitination: the control of NF-[kappa]B activity. Annu Rev Immunol 18:621-663. https:// doi.org/10.1146/annurev.immunol.18.1.621
47. Aktan F (2004) iNOS-mediated nitric oxide production and its regulation. Life Sci 75:639-653. https://doi.org/10.1016/j.lfs.2003.10.042

48. Hara M, Kingsley Cl, Niimi M, Read S, Turvey SE, Bushell AR, Morris PJ, Powrie F, Wood KJ (2001) IL-10 is required for regulatory T cells to mediate tolerance to alloantigens in vivo. J Immunol 166:3789-3796. https://doi. org/10.4049/jimmunol.166.6.3789

49. Zhang P, Ding Z, Liu X, Chen Y, Li J, Tao Z, Fei Y, Xue C, Qian J, Wang X, Li Q, Stoeger T, Chen J, Bi Y, Yin R (2018) Enhanced replication of virulent Newcastle disease virus in chicken macrophages is due to polarized activation of cells by inhibition of TLR7. Front Immunol 9:366. https://doi. org/10.3389/fimmu.2018.00366

50. Chawla A (2010) Control of macrophage activation and function by PPARs. Circ Res 106:1559-1569. https://doi.org/10.1161/CIRCRESAHA .110 .216523

51. Bansal M, Moharir SC, Swarup G (2018) Autophagy receptor optineurin promotes autophagosome formation by potentiating LC3-II production and phagophore maturation. Commun Integr Biol 11:1-4. https://doi. org/10.1080/19420889.2018.1467189

52. Wang Y, Liu J, Zhou JS, Huang HQ, Li ZY, Xu XC, Lai TW, Hu Y, Zhou HB, Chen HP, Ying SM, Li W, Shen HH, Chen ZH (2018) MTOR suppresses cigarette smoke-induced epithelial cell death and airway inflammation in chronic obstructive pulmonary disease. J Immunol 200:2571-2580. https ://doi.org/10.4049/jimmunol.1701681

53. Qian X, Li X, Cai Q, Zhang C, Yu Q, Jiang Y, Lee JH, Hawke D, Wang Y, Xia Y, Zheng Y, Jiang BH, Liu DX, Jiang T, Lu Z (2017) Phosphoglycerate kinase 1 phosphorylates Beclin1 to induce autophagy. Mol Cell 65:917-931.e916. https://doi.org/10.1016/j.molcel.2017.01.027

54. Park HJ, Kim MJ, Ha E, Chung JH (2008) Apoptotic effect of hesperidin through caspase 3 activation in human colon cancer cells, SNU-C4. Phytomedicine 15:147-151. https://doi.org/10.1016/j.phymed.2007.07.061

55. Korsmeyer SJ, Wei MC, Saito M, Weiler S, Oh KJ, Schlesinger PH (2000) Pro-apoptotic cascade activates BID, which oligomerizes BAK or BAX into pores that result in the release of cytochrome c. Cell Death Differ 7:1166-1173. https://doi.org/10.1038/sj.cdd.4400783

56. OltersdorfT, Elmore SW, Shoemaker AR, Armstrong RC, Augeri DJ, Belli BA, Bruncko M, Deckwerth TL, Dinges J, Hajduk PJ, Joseph MK, Kitada S, Korsmeyer SJ, Kunzer AR, Letai A, Li C, Mitten MJ, Nettesheim DG, Ng S, Nimmer PM, O'Connor JM, Oleksijew A, Petros AM, Reed JC, Shen W, Tahir SK, Thompson CB, Tomaselli KJ, Wang B, Wendt MD, Zhang H, Fesik SW, Rosenberg SH (2005) An inhibitor of BCl-2 family proteins induces regression of solid tumours. Nature 435:677-681. https://doi.org/10.1038/natur e03579

57. Starkey Lewis PJ, Moroni F, Forbes SJ (2019) Macrophages as a cellbased therapy for liver disease. Semin Liver Dis 39:442-451. https://doi. org/10.1055/s-0039-1688502

58. Han X, Tian Y, Guan R, Gao W, Yang X, Zhou L, Wang H (2017) Infectious bronchitis virus infection induces apoptosis during replication in chicken macrophage HD11 cells. Viruses 9:198. https://doi.org/10.3390/v9080198

59. Sonoda KH (2008) Association of ocular inflammation and innate immune response. Nippon Ganka Gakkai Zasshi 112:279-297 (in Japanese)

60. Sokolova TM, Poloskov V, Shuvalov AN, Burova OS, Sokolova ZA (2019) Signaling TLR/RLR-mechanisms of immunomodulating action of ingavirin and thymogen preparations. Russ J Biother 18:60-66. https://doi. org/10.17650/1726-9784-2019-18-1-60-66

61. Chhabra R, Ball C, Chantrey J, Ganapathy K (2018) Differential innate immune responses induced by classical and variant infectious bronchitis viruses in specific pathogen free chicks. Dev Comp Immunol 87:16-23. https://doi.org/10.1016/j.dci.2018.04.026

62. Yu L, Zhang X, Wu T, Su J, Wang Y, Wang Y, Ruan B, Niu X, Wu Y (2017) Avian infectious bronchitis virus disrupts the melanoma differentiation associated gene 5 (MDA5) signaling pathway by cleavage of the adaptor protein MAVS. BMC Vet Res 13:332. https://doi.org/10.1186/s1291 7-017-1253-7

63. Sallusto F, Baggiolini M (2008) Chemokines and leukocyte traffic. Nat Immunol 9:949-952. https://doi.org/10.1038/ni.f.214

64. Dar A, Tikoo S, Potter A, Babiuk LA, Townsend H, Gerdts V, Mutwiri G (2014) CpG-ODNs induced changes in cytokine/chemokines genes expression associated with suppression of infectious bronchitis virus replication in chicken lungs. Vet Immunol Immunopathol 160:209-217. https://doi.org/10.1016/j.vetimm.2014.05.004 
65. Cottam EM, Maier HJ, Manifava M, Vaux LC, Chandra-Schoenfelder P Gerner W, Britton P, Ktistakis NT, Wileman T (2011) Coronavirus nsp6 proteins generate autophagosomes from the endoplasmic reticulum via an omegasome intermediate. Autophagy 7:1335-1347. https://doi. org/10.4161/auto.7.11.16642

66. Fung TS, Liu DX (2017) Activation of the c-Jun NH2-terminal kinase pathway by coronavirus infectious bronchitis virus promotes apoptosis independently of c-Jun. Cell Death Dis 8:3215. https://doi.org/10.1038/ s41419-017-0053-0

\section{Publisher's Note}

Springer Nature remains neutral with regard to jurisdictional claims in published maps and institutional affiliations.
Ready to submit your research? Choose BMC and benefit from:

- fast, convenient online submission

- thorough peer review by experienced researchers in your field

- rapid publication on acceptance

- support for research data, including large and complex data types

- gold Open Access which fosters wider collaboration and increased citations

- maximum visibility for your research: over $100 \mathrm{M}$ website views per year

At BMC, research is always in progress.

Learn more biomedcentral.com/submissions 